Acta Universitatis Nicolai Copernici • Pedagogika XXXV/1/2018

Nauki Humanistyczno-Społeczne • Zeszyt 445

DOI: http://dx.doi.org/10.12775/AUNC_PED.2018.010

\title{
Wioletta Kwiatkowska
}

Nicolaus Copernicus University in Toruń

ORCID: 0000-0001-8374-1370

\section{Małgorzata Skibińska}

Nicolaus Copernicus University in Toruń

ORCID: 0000-0001-8972-7529

\section{Kamila Majewska}

Nicolaus Copernicus University in Toruń

ORCID: 0000-0003-3513-4503

\section{Forward, Polonia!}

\section{A review of online educational initiatives for Polish diaspora}

\begin{abstract}
This is an overview article. It presents examples of Internet support for Polish diaspora education, and the promotion of Poland and Polish culture through free access to Internet sources, including open educational resources and e-learning courses. The starting point of this review is therefore to understand the problems of the Polish diaspora and the need to develop an educational offer that takes into account educational and socio-cultural needs of Polish diaspora. The initiative undertaken may also be used to strengthen the activities of Polish scientific departments at foreign universities, schools, consultation centres, teachers, and Polish diaspora organisations that, with their hard work and personal commitment, care for Polish culture, tradition, lan-
\end{abstract}


guage and national values abroad, while requiring support from the Polish government and educational institutions, as well as from academia.

Ke y w ord s: Polish diaspora, education, Internet sources

\section{Marsz Polonia! PRZegląd INTERnetowych inicJatyw EDUKacyjnych NA RZECZ PoloniI}

\section{Streszczenie}

Niniejszy tekst ma charakter przeglądowy. Zaprezentowano w nim przykłady internetowego wsparcia oświaty polonijnej, promocji Polski i polskiej kultury poprzez bezpłatny dostęp do źródeł internetowych, w tym otwartych zasobów edukacyjnych i kursów e-learningowych. Punktem wyjścia jest zrozumienie problemów środowisk polonijnych oraz chęć opracowania mapy treści, stanowiącej ofertę oświatową uwzględniającą potrzeby edukacyjne i społeczno-kulturalne Polonii. Podjęta inicjatywa może również służyć wzmocnieniu działań polskich katedr naukowych na uczelniach zagranicznych, szkół, szkolnych punktów konsultacyjnych, nauczycieli, organizacji polonijnych, którzy swoją ciężką pracą i osobistym zaangażowaniem dbają o polską kulturę, tradycję, język, narodowe wartości za granicami kraju i potrzebują wsparcia polskiego rządu, instytucji oświatowych, a także środowisk akademickich.

Słowa kluczowe: Polonia, edukacja, zasoby internetowe

\section{Introduction}

Doles, or their descendants, can be found in many places around the 1 world. Some of them have ended up outside the country as a result of dramatic historical events, often against their will. Others have emigrated through their own choice, with the usual desire to improve the quality of their lives; however, this choice is often accompanied by difficult life decisions. 
Polonia ${ }^{1}$ communities in different settlements are shaped by a different history and chronology. Their history can be enclosed within certain periods ${ }^{2}$ : (a) the first half of the nineteenth century; (b) the second half of the nineteenth century; (c) 1900-1914; (d) the interwar period (1919-1939); (e) the years 1939-1949-1956; (f) 1956-1980; (g) the period after 1980-1989-2004. Elżbieta Sękowska explains this chronology in terms of the history of major waves of immigrants and the factors affecting them (economic, political, religious, or racial) related to the history of Europe and the internal situation in Poland. This is why the situation of contemporary Polonia in the world is quite diverse, though in many aspects it is extremely similar.

As indicated by the data available in the Report on the Situation of Polonia and Poles Abroad in 2012, prepared by the Ministry of Foreign Affairs, an increasingly common problem is the lack of knowledge of the Polish language, which is used only by a small percentage of the Poles' descendants, and which makes it difficult for them to access Polish culture and get to know contemporary Poland. The problem of alienation and exclusion in the target country becomes extremely difficult due to limited knowledge of the local language and difficulties in getting a job in line with one's professional qualifications. This state of affairs is also intensified by the ignorance of local regulations, sometimes resulting in conflicts with the law or the inability to invest in one's development and the improvement of living conditions.

Moreover, Polonia in the East experience repression manifest in the limiting of Polish education and of contact with Poland and the Polish language. They are cut off from financial support from the Republic of Poland, unable to take advantage of the right to use the Polish language in public spaces, or the lack of the possibility of writing names and surnames of minority representatives in the native language. Therefore,

1 "Polonia" is a Polish term that refers to the Polish diaspora.

2 In E. Sękowska, Język emigracji polskiej w świecie: Bilans i perspektywy badawcze, Kraków 2010, p. 25. 
every effort should be made to support Polonia throughout the world in the following areas of activity ${ }^{3}$ :

- Deepening the knowledge of Polish culture, language, and national traditions among the young generation of the Polish diaspora;

- Popularisation of knowledge about Polish history, including contemporary history and the success of Polish transformations;

- Documenting and disseminating knowledge about the history of Polonia and its contribution to the socio-economic development of a given country;

- Supporting Polonia education, promoting Poland and Polish culture (providing scientific assistance, assistance in organising cultural, educational, and social projects);

- Obtaining the widest possible access to national cultural goods and opportunities to cultivate Polishness, learn the Polish language, support and develop contacts with the Homeland;

- Making the parents aware of the importance of teaching the Polish language to their children;

- Improving the qualifications of Polish language teachers and those teaching in Polish;

- Increasing the presence of Polish culture, especially high culture and its latest achievements;

- Providing the widest possible information to Polish communities about their international rights and standards in the sphere of national minorities;

- Help in developing media techniques and the Internet in promoting Polonia activities;

- Organising educational trips to Poland (e.g., summer schools, camps, workshops, etc.) related to learning about Polish history and culture.

In order to seek help and support, Poles living abroad reach out to foundations, consultancies, and even the Internet, where they can use

3 Ministerstwo Spraw Zagranicznych, Raport o sytuacji Polonii i Polaków za granica. 2012, Warszawa 2013, http://www.msz.gov.pl/resource/d44dcd91-ed03-4e64-a475-b56dbece5a46:JCR [03.22.2017]. 
the curricular offer of Polish online schools and advance their education at various levels.

The starting point is therefore an understanding of the problems of the Polish diaspora and the development of a network of contacts with an offer that takes into account its educational and socio-cultural needs. This will allow for an agreement and coordination of plans and activities, and thus lead to greater social integration. It would also be important to strengthen Polish scientific departments at foreign universities, schools, consultancies, teachers, and Polish diaspora organisations that, with their hard work and personal commitment, care for Polish culture, tradition, language, national values abroad, and need support from the Polish government, educational institutions, as well as academia. It seems necessary to undertake actions, cooperation, and dialogue in order to create an Internet Community of Polish Learners for both those remaining in the country and those abroad.

This can be done with the support of remote technologies by organising, among others: online classes, seminars, workshops using video conferencing systems (webinars), discussion forums, thematic blogs, Facebook support groups, sharing information on Twitter, etc. It is worth noting that any assistance will be an expression of solidarity and gratitude for caring for the upbringing of young Poles and for cultivating the Polish national heritage. It is necessary to ensure their education to preserve Polishness, historical memory and language, while facilitating their ability to return to the country in the future and work for the development helping subsequent generations of Poles.

\section{E-learning for immigrants}

Poles living abroad need support in order to learn the Polish language, literature, history and to cultivate and openly represent Polish culture and customs. E-learning can serve as an opportunity for our compatriots to meet educational needs by providing education, supplementing qualifications, closer contact with one's family, language and culture for the development of a national identity, without having to leave the place of residence. It can be a platform for communication, cooperation 
and for establishing and tightening mutual relations with communities and Polish diaspora institutions.

Academic institutions in Poland are more and more willing to set in motion programs of study, remote training aimed at greater openness, flexibility and the commercialisation of knowledge, thus increasing their own competitiveness and strengthening their position on the European and global educational market. Such initiatives require a wellprepared teaching staff with knowledge of the specifics, course and conditions of of the online teaching process, competences in the area of creating interactive teaching materials and conducting classes using various online education methods. E-learning enables learning regardless of time and place, facilitating access to didactic materials on the educational platform and contact with the teachers.

The learners are obliged to demonstrate active self-work and cooperation in an online course, to complete tasks by set dates, to participate in several yearly stationary conferences and to take exams during the university session. They also have the opportunity to obtain various scholarships if they meet the relevant criteria. Students are prepared to work with an internet platform, while being familiarised with the expectations and requirements set by the teachers and the university.

What is important is that one can become a member of an academic community while living abroad. At present, online education aims to undertake various types of educational activities outside the e-learning platform, so initiating group collaboration, interaction, building relationships and ties between the members of the educational online group. All of these efforts are aimed at developing the idea of selflearning and lifelong education.

As an example of remote initiatives undertaken for the Polish community, one can point to the Internet portal of the Centre for the Development of Polish Education Abroad (Ośrodek Rozwoju Polskiej Edukacji za Granica, or ORPEG) ${ }^{4}$, which organises, supports and promotes various types and forms of continuing education and improvement (including e-learning) in the area of knowledge about Poland, language skills

4 Ośrodek Rozwoju Polskiej Edukacji za Granica (ORPEG), http://www.orpeg. pl/index.php/home/o-orpeg [06.26.2017]. 
and Polish culture among Poles living abroad. They provide access to the didactic offer of school consultation points and school textbooks, supporting the professional development of teachers, while organising and popularising meetings, conferences, training and celebrations in the name of promoting Polishness and national values.

Another important project is the Polish Internet Schools portal $\mathrm{Li}$ bratus $^{5}$, which allows free online education for children of Poles living abroad at the level of kindergarten, primary and middle school. Classes are carried out in the form of e-learning using interactive teaching materials and weekly online meetings with the teacher (webinar). In this form of learning, it is necessary that the child has the help and support of their parents, who are responsible for working with the child at home. On his blog, Bogusław Śliwerski is sceptical about this initiative, expressing doubts about this way and quality of education ${ }^{6}$. Unfortunately, it is difficult to verify his opinion due to the inability to gain access to resources from the "Guest" account and the lack of such rights.

History for Polonia ${ }^{7}$ is an example of an e-learning platform that presents didactic materials devoted to the history of Poland addressed to teachers and youth at the level of primary schools (grades 4-6) and junior high school students staying abroad. At each level, 15 lessons are planned. One can access the developed materials regardless of the place and time. Students finishing the course can receive an additional certificate confirming their participation in this project. It is a project run by the Children's Foundation University of Curious History, cofunded by the Ministry of Foreign Affairs and under the patronage of the Centre for the Development of Polish Education Abroad. The disadvantage of this platform is the possibility of only students and teachers logging on to it, hence lacking access for guests who would like to get acquainted with the resources posted there.

${ }^{5}$ Polskie Szkoty Internetowe Libratus, https://www.libratus.edu.pl/ [06.26.2017].

${ }^{6}$ Polskie szkoty internetowe... ale $w$ przeważajacej mierze nie $w$ Polsce, czyli edukacja domowa dla emigracji ["Polish internet schools ... but predominantly not in Poland, or home education for emigrants"], http://sliwerski-pedagog.blogspot. com/2016/01/polskie-szkoy-internetowe-ale-nie-w.html [06.26.2017].

7 Historia dla Polonii, http://www.historiadlapolonii.pl/ [06.26.2017]. 
It is also worth mentioning the rich didactic offer of the Polish Virtual University [Polski Instytut Wirtualny $]^{8}$, which allows the study of different fields in a remote form and can be an opportunity for young Poles living abroad to obtain an education. Similar activities were also undertaken at the University of Nicolaus Copernicus in Torun by launching a new field of study "Media Pedagogy" in the form of e-learning and encouraging people who have Polish citizenship and live in other countries to study ${ }^{9}$.

Massive open online courses (MOOCs), free and generally available to an unlimited number of Internet users, without having to meet formal conditions related to access and ease of use, are becoming more and more popular. We are dealing here with informal education, that is outside the school, university, by organising trainings, workshops and improvement courses, mainly based on educational materials bearing the content and tasks checking the students' knowledge. The offer of courses based on the MOOC model presents the challenge of independent learning, while maintaining high motivation and self-control. At the Nicolaus Copernicus University in Torun, open e-learning courses are available free of charge, including: e-learning methodologies, computer technologies used in education of disabled people, copyright in distance learning, graphics and computer animation in educational applications ${ }^{10}$. This initiative is an attempt to reach all those interested, as well as a means of promoting the university and achieving greater educational mobility.

8 Polski Uniwersytet Wirtualny, http://www.puw.pl/ [06.26.2017].

9 W. Kwiatkowska, K. Majewska, M. Skibińska, Pedagogika medialna na Uniwersytecie Mikołaja Kopernika w Toruniu jako przykład studiów stacjonarnych $w$ formie online, "E-mentor" 2017, no. 1 (68), http://www.e-mentor.edu.pl/artykul/index/numer/68/id/1288/ [06.26.2017].

10 Portal Edukacyjny Uniwersytetu Mikołaja Kopernika, http://portal.umk.pl/ [06.26.2017]. 


\section{Open-access educational resources}

Modern generations use media as a natural means of communication. The Internet has become a common source of immediate information and a form of permanent contact. Freedom and ease of access to Internet resources are conducive to acquiring content without spatial or temporal restrictions. Currently, more than half of the Earth's inhabitants have access to the Internet, of which $77.4 \%$ of Europeans and $88.1 \%$ of Americans (North America) ${ }^{11}$. It would seem, therefore, that the Internet can be very helpful in solving Polonia's problems all over the world, being both an attractive medium for young people, as well as offering broad access to information and educational materials and the possibility of using services conducive to building online communities. For Poles from the East, it will undoubtedly facilitate the possibility of organising themselves in groups and gain access to important and reliable information, as well as educational materials enabling the learning of Polish language, Polish history and culture to strengthen the Polish national identity. Polonia from the West will surely find attractive materials that promote Polishness and encourage people to use the Polish language and maintain the tradition and culture of our country.

Undoubtedly, in the context of the uninhibited and costless use of learning materials, one should be interested in open educational resources (OER), both education authorities, teachers, as well as parents and children of the Polish diaspora. Open Educational Resources are "materials that are publicly available on the Internet (without access control), published together with the right to further use (for this purpose, the use of so-called free licences are recommended or a transfer to the public domain) and most often developed in an open manner"12.

By downloading OER, one can use them without the author's direct consent, usually free of charge, and can modify their form and content

11 According to the Internet World Stats, http://www.internetworldstats.com/ stats.htm [03.10.2017].

12 Mapa Otwartych Zasobów Edukacyjnych, https://men.gov.pl/wp-content/ uploads/2013/07/mapa_oze.pdf [01.17.2017]. 
to suit one's needs and, most importantly, do it legally and ethically. The average person does not think about the fact that most of the materials (photos, music, pictures, films, documents, etc.) seen online have an author or owner who may not consent to the use of their property.

Table 1

Levels of openness (level of freedom in accessing the Internet)

Public domain (ㅈ) $)$ and free licences

(Creative Commons; CC):

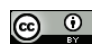

Necessary: evoking authorship

\section{(c) (1) (2)}

Necessary: sharing made available on the same conditions

Free licences (Creative Commons; CC) - limited open-access resources:

\section{(c) (1) (9)}

Necessary: evoking authorship and solely for non-commercial use

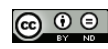

Necessary: evoking authorship and prohibition against distribution of modified content.

All rights reserved(@)

Necessary: express permission of the author and for use solely under specified conditions
The publication is available free of charge, together with the guarantee of full rights to use, copy, distribute, process, etc.

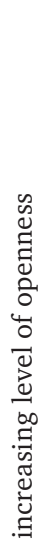

The publication is partially open-access: available for free with possibility of reuse, but within a limited scope.

The publication can only be used as part of permitted private or public use.

Source: on the basis of Otwarta lekcja https://uwolnij.podrecznik.org/wp-content/uploads/ 2015/01/Otwarta_lekcja_scenariusz.pdf 


\section{Books, reading materials, textbooks, educational materials}

Teachers and representatives of Polonia can use free collections of books available on the Internet. One can use them as a source of knowledge about Poland, its history and present culture, but also as an opportunity to encounter and experience the Polish language. Many teachers will also find open textbooks on the Internet for use in whole or selected fragments during their classes. One of the examples here is the WOLNE LEKTURY [Free Books] internet library (https://wolnelektury. $\mathrm{pl} /$ ). There are 4,436 works in its collection, including many school books recommended for use by the Ministry of National Education, which have already been put into the public domain. The library also has several hundred audiobooks read by such actors as Danuta Stenka, Jan Peszek and Andrzej Chyra. Audiobooks are also available in a format adapted to the needs of the visually impaired, the blind, and those with reading difficulties.

The entire collection included in the Wolne Lektury library can be viewed free of charge, listened to and downloaded, as well as shared with others and quoted ${ }^{13}$. One interesting source for older and younger generations may also be the POLONA portal (https://polona.pl) - a tool allowing for the widespread use of the National Library's treasury and magazine collections. Teachers and parents will probably be interested in open-access textbooks and educational publications. The online textbook WŁĄCZ POLSKE [Turn On Poland] (http://wlaczpolske.pl/) is a tool that allows one to create personalised sets of content without restrictions and free of charge, adjusted to the age and level of Polish language proficiency. Available materials include early school education, Polish language, knowledge about Poland, and the history and geography of Poland ${ }^{14}$.

13 Internet library Wolne lektury, https://wolnelektury.pl/info/o-projekcie/ [03.20.2017].

${ }^{14}$ Internet textbook Właccz Polskę, http://wlaczpolske.pl/index.php?eta$\mathrm{p}=10 \& \mathrm{i}=762$ [03.20.2017]. 
Another suggestion for elementary education on the basis of open access is DARMOWE PODRECZNIKI DLA KL. I-III [Free Textbooks for Grades 1-3] (https://naszelementarz.men.gov.pl). Teachers can use the ideas contained in these textbooks, adjusting them to the capabilities of their students, expanding them, deepening, or introducing their own. An online methodological guide is prepared for each part of the textbook, which contains all educational content, sample scenarios or ideas for use in the classroom, sample worksheets and proposals for teaching activities. Tips for parents are also available ${ }^{15}$.

An interesting proposition that enables the inclusion of information and communication technologies for teaching Polish is the publication Polish language 2.0 - the use of modern technologies in teaching Polish language (http://www.efundacja.org/projekty.html). Thanks to this edition, one can get to know the tools that will undoubtedly encourage the young generation to play with the Polish language. Educators can also find support in the form of access to educational materials (e.g., classroom scenarios, worksheets, presentations, charts, ideas, inspirations, etc.), among others on various knowledge portals for teachers, e.g., SCHOLARIS (http://scholaris.pl), OŚRODEK ROZWOJU EDUKACJI [Educational Development Centre] (https://www.ore.edu.pl) or BAZA NARZĘDZI DYDAKTYCZNYCH [Database of Didactic Tools] (http://bdp.ibe.edu.pl). The afore-mentioned portals are characteristic databases containing free, electronic educational resources from all subjects and adapted to all stages of education.

The suggestions of open-access Internet resources mentioned above allow for contact with the written Polish word, both old and modern, while allowing the use of the same resources as those used by teachers and students in Poland. Teachers can find inspirational ideas for classes and use ready-made materials, which should facilitate their difficult work. All of this is available to anyone who has access to the Internet, without the need for fees, registration or login-in formation.

15 Nasza szkoła - free textbooks for grades 1-3, https://naszelementarz.men. gov.pl/category/dla-nauczycieli/ [03.20.2017]. 


\section{Open-access culture and the history of Poland}

According to Leon Dyczewski ${ }^{16}$, Polish identity is shaped by events and national values, i.e.,

- important historical national acts

- the work of great artists;

- national epics;

- important national figures;

- places of national remembrance;

- places of religious worship;

- national symbols;

- the Polish language and annual rituals and customs of the Polish nation, preserved for centuries;

- behaviour disseminated in society.

Taking care of shaping and maintaining Polish identity among Polonia, especially young generations, the above values should be promoted. Hence, the Internet, due to its range, simplicity of use and attractive form of communication, will be a perfect tool for achieving this goal.

The Institute of Ethnology and Cultural Anthropology of the Adam Mickiewicz University in Poznań, based on a free licence, provided the CYFROWE ARCHIWUM IM. JÓZEFA BUSZTY [Jozef Buszta Digital Archive] (http://cyfrowearchiwum.amu.edu.pl). The archive contains materials showing phenomena related to traditional culture, i.e., photographs, audio recordings, video recordings and texts collected during ethnographic and anthropological research conducted by the Institute. As part of another project titled WIRTUALNE MUZEA MAŁOPOLSKI [Virtual Museums of Lesser Poland] (http://muzea.malopolska.pl), digital exhibits from 39 museums from Lesser Poland are made available in digital form. The NATIONAL MUSEUM IN WARSAW (http://cyfrowe. mnw.art.pl/dmuseion) also collects digital images and works of art, many of which are already in the public domain and can be download-

16 L. Dyczewski, Kultura w całościowym planie rozwoju, Warszawa 2011, p. 42, 72-73. 
ed and distributed without restrictions. E_MUZEUM (http://e-muzeum.eu/index.php) allows all interested parties quick access to information on collected exhibits in museums in Poland, allowing for any search and creation of virtual walks, galleries and thematic exhibitions according to the thematic division of the collections. ZABYTEK.PL (https://zabytek.pl/pl) presents Polish objects inscribed on the UNESCO World Heritage List. Access rights to individual digital materials are described in the individual resources.

In the NINATEKA digital project (http://ninateka.pl/) run by the National Audiovisual Institute, there are over 6000 films and broadcasts about culture, including documentary and feature films, animations, experimental films, theatre and opera performances, concert recordings, reports documenting cultural and social life and radio programmes. Here, $98 \%$ of materials can now be viewed and listened to free of charge. By registering with Ninateka Edu, one gains completely free access to audiovisual materials, class scripts and exercises for educational purposes ${ }^{17}$.

In the event of difficulties associated with visiting Poland, the Internet sites suggested above will certainly facilitate learning about significant places in Poland, as well as about the artefacts of its culture. It would not be possible to shape Polish identity without knowing the history of Poland, which is a collection of knowledge about key events and national values. It is crucial, therefore, that the representatives of Polonia and their teachers have free access to reliable and up-to-date information about the history of our nation. The historical portal POLISHHISTORY.PL (http://www.polishhistory.pl) may be helpful. This is an internet project of the Museum of Polish History in Warsaw whose aim is to collect and share information useful to domestic and foreign researchers of Polish history. Using the database one can learn about museums, libraries, archives and historical studies in Poland. The collections of digital resources, historical films and the collection of scien-

17 Ninateka, http://ninateka.pl/strona/jak-korzystac [03.22.2017]. 
tific and educational texts of BazHum are constantly updated (http:// www.polishhistory.pl/index.php?id $=111)^{18}$.

The Museum of Polish History has also taken care of the education of future generations by launching a vortal for history teachers BELFER (http://www.belfer.muzhp.pl), which offers access to didactic and methodological materials, such as outlines, scenarios and maps not published in atlas. The MHP in Warsaw also financially supported the web project HISTORIA DLA DZIECI [History for Children] (http://historiadladzieci.pl), whose aim is to populariae the history of Poland and of patriotic attitudes, especially among children and youth, as well as the dissemination of national heritage. There are 14 radio plays available on the site in the form of extraordinary stories about the most significant events in the history of Poland, which can be downloaded free of charge. The radio plays are aimed at children from 6-12 years old. Each story is accompanied by a song connected thematically with the story made by children from the Music Scene NUTKA, which is also freely available ${ }^{19}$.

In turn, the educational portal of the Institute of National Remembrance PAMIĘĆ.PL [Memory.pl] (http://pamiec.pl) contains in one place the scope of educational activity of the Institute of National Remembrance. With it, one can find information about exhibitions, publications and socio-educational activities of the Institute of National Remembrance, film coverage of events, a historical calendar and a digital library. Under the "Education" tab, there are also ready-to-download educational materials for students ${ }^{20}$.

The history and symbolism of the Polish coat of arms are the leitmotiv of the WIRTUALNE MUZEUM ORŁA BIAŁEGO [The Virtual Museum of the White Eagle] (http://orzelbialy.edu.pl). The site contains information and galleries of illustrations showing the history of the White Eagle in various historical periods, as well as various download-

18 History portal polishhistory.pl, O portalu, http://www.polishhistory.pl/index.php?id=97 [03.22.2017].

19 Historia dla dzieci, http://historiadladzieci.pl/o-projekcie.html [03.22.2017].

20 Instytut Pamięci Narodowej, Portale - Pamięć.pl, https://ipn.gov.pl/pl/edukacja-1/portale/33352,Pamiecpl.html [03.22.2017]. 
able didactic materials for classes on the topic of: Where did our emblem come from? (lesson plan, work card, presentation) ${ }^{21}$.

It is also worth noting that the majority of the open-access initiatives described also have English-language versions, facilitating the navigation of resources for people who are more fluent in English than in Polish. There are also many more materials dispersed throughout the Internet devoted to Polish topics, so if one plans to use them in a free and legal manner, one should check whether they are made available under a Creative Commons licence or are in the public domain.

\section{Educational initiatives online}

The increase in the number of Internet users has directly contributed to the intensification of educational initiatives undertaken online. Of particular interest here are the noteworthy activities undertaken by teachers, therapists or speech therapists who, using blogs, social networks or websites, provide both traditional worksheets, educational games and multimedia exercises to facilitate learning the Polish language. These materials include:

- readers for printing ${ }^{22}$, listening ${ }^{23}$ or simultaneous listening and reading ${ }^{24}$,

- poems by Polish poets, children's works ${ }^{25}$,

- verbal games, e.g., rhymes, word spreads ${ }^{26}$,

21 T. Pietras, Wirtualne Muzeum Orła Białego, O stronie, http://orzelbialy.edu. $\mathrm{pl} / \mathrm{blog} /[03.22 .2017]$.

22 SuperKid.pl, Zapewnij dzieciom dobry start, https://www.superkid.pl/czytanki-i-cwiczenia [04.25.2017].

23 MiniMini+, Czytanki Rybki MiniMini, http://www.miniminiplus.pl/filmy/ pokaz/co-lubia-dzieci [04.25.2017].

24 Czytanki Dla Dzieci Jan Brzechwa - Skarżypyta, https://www.youtube.com/ watch?v=2i_h1Te29lE\&t=1s [04.25.2017].

25 PisuPisu, Wiersze, http://pisupisu.pl/2/wiersze [04.25.2017]. Wierszyki dla dzieci, http://wierszykidladzieci.pl/ [04.25.2017].

26 Ortografka.pl, http://www.ortografka.pl/pisownia-rz-i-z/grzybiarz/gra/ wykreslanka [04.25.2017]. PisuPisu, Zabawy słowne, http://pisupisu.pl/2/slowne-zabawy [04.25.2017]. 
- traditional and multimedia tasks to learn spelling ${ }^{27}$,

- cards that enrich the learning of writing 28 .
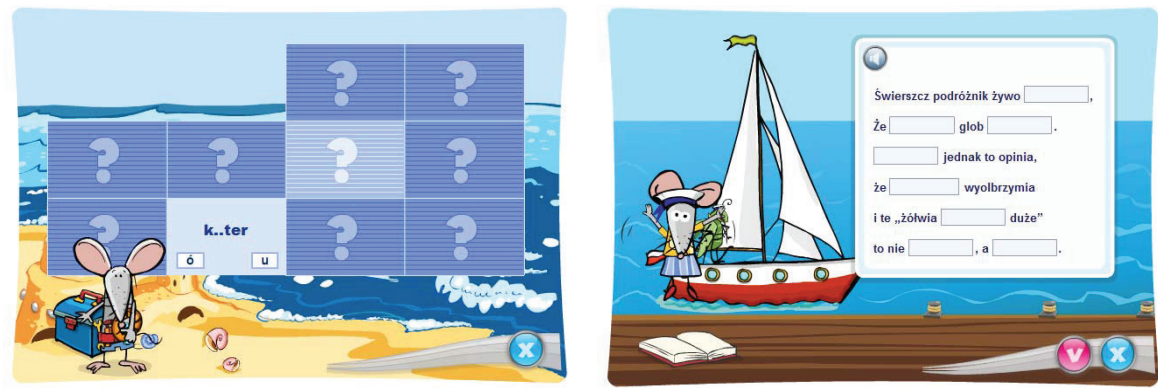

Image 1. Orthographic exercises with Sebastian and Matylda

Source: Scholaris.pl Portal

The resources available online also facilitate the promotion of Polish traditions, including:

- rites $^{29}$,

- legends ${ }^{30}$,

- regional costumes ${ }^{31}$,

- history, songs, etc ${ }^{32}$.

27 Ortografka.pl, Segregowanie akt, http://www.ortografka.pl/pisownia-a-i-e/konstanty/gra/akta [04.25.2017Portal Scholaris, http://www.scholaris.pl/resources/run/id/49508 [04.25.2017], Portal Scholaris, http://www.scholaris.pl/ resources/run/id/49458 [04.25.2017], Portal Scholaris http://www.scholaris.pl/ resources/run/id/49507 [04.25.2017], Portal Scholaris, http://www.scholaris.pl/ resources/run/id/49424 [04.25.2017].

28 Bystre Dziecko, Wczesna edukacja twojego dziecka, http://bystredziecko.pl/ nauka-pisania-dla-dzieci/ [date 04.25.2017].

29 SuperKid.pl, Polskie obrzędy i zwyczaje ludowe, https://www.superkid.pl/ obrzedy-i-zwyczaje-ludowe [04.25.2017].

30 Bajkowyzakatek, http://bajkowyzakatek.eu [04.25.2017].

31 Polskie Stroje Ludowe, http://stroje.pl/ [date accessed: 04.25.2017].

32 Polska Tradycja, http://www.polskatradycja.pl/piesni.html [04.25.2017]. 
Of further note are the websites that allow visiting:

- regions and corners characteristic of our country ${ }^{33}$,

- museums $^{34}$,

- castles, etc. ${ }^{35}$

Educational games combining elements of learning and playing are particularly interesting and commendable ${ }^{36}$. Their accessible form, colourful graphics and rich content contribute to acceptance from both students and teachers ${ }^{37}$.
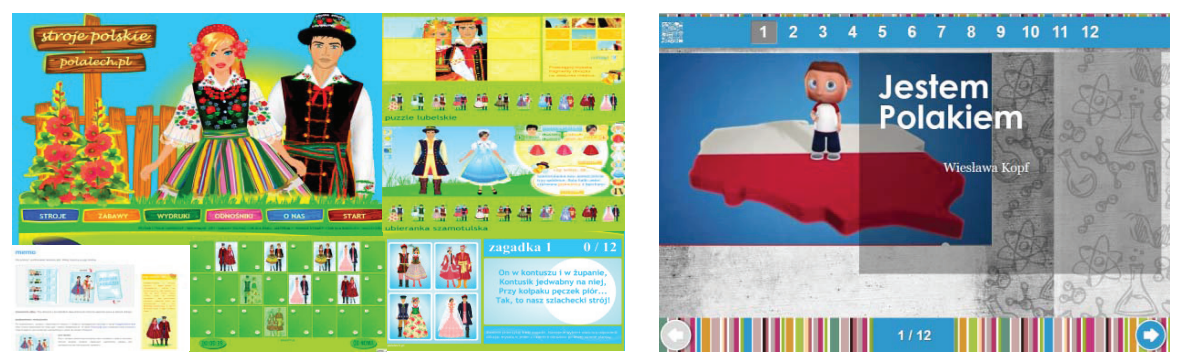

Image 2. Educational games

Source: Developed based on online resources.

A constant presence in virtual space also guarantees access to resources supporting pedagogical and speech therapy. These materials are available online or for download and installation. The quality of

33 Kultura dla dzieci w sieci, http://kula.gov.pl [04.25.2017].

34 Muzeum Małopolski, http://muzea.malopolska.pl [04.25.2017], Muzeum Zamkowe w Malborku, http://www.zamek.malbork.pl/ [04.25.2017], Kultura Dostępna, https://kulturadostepna.pl/on-line/wirtualne-muzea [04.25.2017].

35 Zamek Królewski w Warszawie, http://www.pano360.pl/projekty/zamek/ virtualtour.html [04.25.2017].

36 Stroje polskie, http://www.polalech.pl/ [04.25.2017], Jestem Polakiem, https://www.minstructor.pl/embed/4675603806552064 [04.25.2017].

37 K. Majewska, Multimedialne gry dydaktyczne $w$ opinii studentów edukacji wczesnoszkolnej, In: Lifelong Learning, V. Tanaś, W. Welskop (eds.), Wydawnictwo Naukowe Wyższej Szkoły Biznesu i Nauk o Zdrowiu, Łódź 2015, pp. 169-176. 
the study and the content of the published exercises is very diverse from simple and affordable to complicated, complex tasks with interactive elements.

Access to free content is wide, but it is worth mentioning paid services, programs and interactive educational sets that support the work of a speech therapist at various levels of education. Interesting solutions in this area are proposed by the following companies: Young Digital Planet $^{38}$, Komlogo ${ }^{39}$, Polimedia LLC ${ }^{40}$. The work of speech therapists, as well as parents, can be successfully supported by the Mimowa.pl website, which contains a set of exercises to improve the pronunciation of children with problems with lisping or rhotacism. The protagonist of the site also accompanies the child as he or she solves tasks supporting general pronunciation, pronunciation of sounds $k$, $k i$ (kappacism), $g, g i$, $h, h i$ (gammacism). The portal also includes tasks in the field of auditory and visual analysis, synthesis, spatial orientation and perceptiveness. Some of the exercises contain commands that provoke facial and tongue gymnastics ${ }^{41}$.

One interesting and recommendable solution motivating people from various age groups to learn Polish and about the Polish culture is the use of applications for phones or tablets. The range of applications available online means that, with their help, Poles living outside our country can:

38 Young Digital Planet, Diagnoza I terapia logopedyczna, http://sklep. ydp.pl/pol_m_Terapia-i-rozwoj_Diagnoza-i-terapia-logopedyczna-207.html [04.25.2017].

39 Wydawnictwo Komlogo, https://www.komlogo.pl/index.php/komlogo/ wszystkie/komlogo-programy-komputerowe [04.25.2017].

40 Kraina dźwięków, http://www.krainadzwiekow.pl/pl/site/glowna [04.25.2017].

41 Mimowa.pl, http://www.mimowa.pl/ [04.25.2017]. 
- learn about individual letters and words (Świat liter ${ }^{42}$, Alfabet polski dla dzieci abecadło ${ }^{43}$, Pierwsze słowa - Nauka dzieci ${ }^{44}$, Uczymy i bawimy. Polski free ${ }^{45}$, Nauka Polskiego 6000 Słów $^{46}$ ),

- consolidate the learning of reading (Nauka czytania metodą sylabową ${ }^{47}$, Globalne Czytanie 1 Klasa SP ${ }^{48}$ ),

- practice Polish grammar and fluent speaking (Ćwiczenia Mowy: darmowe gry $3+{ }^{49}$, J. polski. Szkoła Podstawowa ${ }^{50}$, Learn Polish, Speak Polish ${ }^{51}$, Польский язык за 7 уроков ${ }^{52}$, Польська мова безкоштовно ${ }^{53}$ ),

42 Świat liter, https://play.google.com/store/apps/details?id=com.baglajdev. swiatliter [04.25.2017].

43 Alfabet polski dla dzieci abecadło, https://play.google.com/store/apps/details?id=com.mobinet.alphaalphabet [04.25.2017].

44 Pierwsze słowa - Nauka dzieci, https://play.google.com/store/apps/details?id=pl.tweeba.mobile.edumobile [04.25.2017].

45 Uczymy i bawimy. Polski free, https://play.google.com/store/apps/detail$\mathrm{s}$ ?id=free.langame_pl.rivex\&hl=pl [04.25.2017].

46 Nauka Polskiego 6000 Słów, https://play.google.com/store/apps/details?i$\mathrm{d}=$ com.funeasylearn.polish\&hl=pl [04.25.2017].

47 Nauka czytania metodą sylabową, https://play.google.com/store/apps/details?id=com.orbisign.android.nauka.czytanie\&hl=pl [04.25.2017].

48 Globalne Czytanie 1 Klasa SP, https://play.google.com/store/apps/details?id=eu.android_lab.globalne_czytanie_klasa1 [04.25.2017].

49 Ćwiczenia Mowy: darmowe gry 3+, https://play.google.com/store/apps/ details?id=com.hedgehogacademy.sequencesfree\&hl=pl [04.25.2017].

50 J. polski. Szkoła Podstawowa, https://play.google.com/store/apps/details?id=pl.preclaw.jpolski\&hl=pl [04.25.2017].

51 Learn Polish, Speak Polish, https://play.google.com/store/apps/details?i$\mathrm{d}=$ com.atistudios.italk.pl\&hl=pl [04.25.2017].

52 Польский язык за 7 уроков, https://play.google.com/store/apps/details?id=ru.ookamikb.speakasappo\&hl=pl [04.25.2017].

53 Польська мова безкоштовно, https://play.google.com/store/apps/details?i$\mathrm{d}=$ pl.tweeba.mobile.learning.uapl\&hl=pl [04.25.2017]. 
- reduce or eliminate speech therapy problems (Szumi Mi - Logopedia na Wesoło ${ }^{54}$, Logopedia: ćwiczenia artykulacyjne ${ }^{55}$, Wierszyki logopedyczne ${ }^{56}$ ),

- learn about interesting facts or test your knowledge about Poland, history, geography, sport and entertainment (Zgaduj: wiedza o Polsce $^{57}$, Szlachecka przygoda ${ }^{58}$, Historia polska ${ }^{59}$, ZnajZnak ${ }^{60}$, Zabytki w Polsce ${ }^{61}$, Zamki Polskie ${ }^{62}$, Polskie Szlaki ${ }^{63}$, Polska inspiruje ${ }^{64}$ ),

- elements of Poland's history, culture, geography and national heritage.

54 Szumi Mi - Logopedia na Wesoło, https://play.google.com/store/apps/details?id=pl.yummy.mimowaszumki\&hl=pl [ 04.25.2017].

55 Logopedia: ćwiczenia artykulacyjne, https://play.google.com/store/apps/ details?id=com.pmqsoftware.logopedia.pl\&hl=pl, wraz z wideo i opisem ćwiczeń logopedycznych dla dzieci, dostępnym na stronie internetowej: http://www.cwiczenia-logopedyczne.pl [04.25.2017].

56 Wierszyki logopedyczne, https://play.google.com/store/apps/details?i$\mathrm{d}=$ eu.uvdb.education.speechtherapy.poems\&hl=pl [04.25.2017].

57 Zgaduj: wiedza o Polsce, https://play.google.com/store/apps/details?id=pl. lukkob.zgaduj [04.25.2017].

58 Szlachecka przygoda, https://play.google.com/store/apps/details?id=com. edufun.szlacheckaprzygoda [04.25.2017].

59 Historia polska, https://play.google.com/store/apps/details?id=com.mwiacek.historia.polska [04.25.2017].

60 ZnajZnak, https://play.google.com/store/apps/details?id=air.pl.ipn.znajznak [04.25.2017].

61 Zabytki w Polsce, https://play.google.com/store/apps/details?id=air.pl.com. softproject.nid.zabytki.NidApkNew [04.25.2017].

62 Zamki Polskie, https://play.google.com/store/apps/details?id=com.plcastles [04.25.2017].

63 Polskie Szlaki, https://play.google.com/store/apps/details?id=pl.polskieszlaki.PolskieSzlaki [date accessed: 04.25.2017].

64 Polska inspiruje, https://play.google.com/store/apps/details?id=pl.rodziceprzyszlosci.polskainspiruje [date accessed: 04.25.2017]. 
- consolidate knowledge about legends (iOjczysty ${ }^{65}$, Legenda o Smoku Wawelskim ${ }^{66}$ ).

Mobile applications can be a perfect complement to traditional forms of teaching and all the more so since the popularity of mobile devices is constantly growing. It is therefore a convenient, fast and attractive way to access educational content for people of all ages.

Web-based educational initiatives play a significant role for a wide group of readers who want to learn, as well as teach the Polish traditions, customs and language. Thanks to free computer resources, individual or group work (both at home and at school) becomes easier. The afore-mentioned educational materials used by Polish teachers on a daily basis are particularly valuable from the point of view of the Polish diaspora living abroad. They stimulate cognitive activity, promote Polish traditions and customs, and bring history and geographical considerations closer. Extremely helpful are also applications that facilitate learning: writing, reading or correct speaking in Polish. Thanks to them, educational activity at home or at school becomes easier.

\section{Summary}

An extremely urgent issue has been raised by the education and upbringing of Poles living abroad in a tradition based on national, religious and cultural values. It is also important to have a sense of national belonging and being aware of its value, to take care of the language, history and geography of one's own country, with the help of family members, educators, teachers, national institutions and the entire Polish community.

The considerations discussed above are intended to bring to the readers' awareness ways in which this challenge can be met using Internet resources, including open-access educational resources, e-learning

65 iOjczysty, https://play.google.com/store/apps/details?id=pl.rodziceprzyszlosci.iojczysty [04.25.2017].

${ }^{66}$ Legenda o Smoku Wawelskim, https://play.google.com/store/apps/details?id=smok.dev [04.25.2017]. 
courses, educational games, etc., but above all, the activity of people who want to care for and promote Polish patriotic, historical and cultural values, and who feel such a duty toward their homeland and their compatriots. Polish academic circles, and in particular pedagogues, should also seek such activities, creating various initiatives and engaging in propagating Polishness and historical memory. Activities undertaken for compatriots living outside our country are important because free access to educational materials and educated teaching staff is much more difficult than it is in Poland.

\section{References:}

Biblioteka internetowa Wolne lektury, https://wolnelektury.pl/info/o-projekcie/ [data dostępu: 2-0.03.2017].

Dyczewski, Leon. Kultura $w$ całościowym planie rozwoju. Warszawa: Instytut Wydawniczy Pax, 2011.

Historia dla dzieci, http://historiadladzieci.pl/o-projekcie.html [data dostępu: 22.03.2017].

Historia dla Polonii, http://www.historiadlapolonii.pl/ [dostęp: 26.06.2017].

Instytut Pamięci Narodowej, Portale-Pamięć.pl, https://ipn.gov.pl/pl/edukacja-1/portale/33352,Pamiecpl.html [data dostępu: 22.03.2017].

Kwiatkowska, Wioletta, Majewska, Kamila, Skibińska, Małgorzata. "Pedagogika medialna na Uniwersytecie Mikołaja Kopernika w Toruniu jako przykład studiów stacjonarnych w formie online", E-mentor 1(68) (2017), http://www.e-mentor.edu.pl/artykul/index/numer/68/id/1288/ [dostęp: 26.06.2017].

Majewska, Kamila. "Multimedialne gry dydaktyczne w opinii studentów edukacji wczesnoszkolnej". In: Lifelong Learning, ed. Violetta Tanaś, Wojciech Welskop, p. 169-176. Łódź: Wydawnictwo Naukowe Wyższej Szkoły Biznesu i Nauk o Zdrowiu, 2015.

Mapa Otwartych Zasobów Edukacyjnych, https://men.gov.pl/wp-content/ uploads/2013/07/mapa_oze.pdf [data dostępu: 17.01.2017]

Nasza szkoła - darmowe podręczniki dla kl. I-III, https://naszelementarz.men. gov.pl/category/dla-nauczycieli/ [data dostępu: 2-0.03.2017]

Ninateka, http://ninateka.pl/strona/jak-korzystac [data dostępu: 22.03.2017]. 
Ośrodek Rozwoju Polskiej Edukacji za Granica (ORPEG), http://www.orpeg.pl/ index.php/home/o-orpeg [dostęp: 26.06.2017].

Pietras, Tomasz. Wirtualne Muzeum Orła Białego, http://orzelbialy.edu.pl/ blog/ [data dostępu: 22.03.2017].

Podręcznik internetowy. Wtącz Polskę, http://wlaczpolske.pl/index.php?eta$\mathrm{p}=10 \& \mathrm{i}=762$ [data dostępu: 2-0.03.2017].

Polski Uniwersytet Wirtualny, http://www.puw.pl/ [dostęp: 26.06.2017].

Polskie Szkoty Internetowe Libratus, https://www.libratus.edu.pl/ [dostęp: 26.06.2017].

Polskie szkoty internetowe... ale w przeważajacej mierze nie w Polsce, czyli edukacja domowa dla emigracji, http://sliwerski-pedagog.blogspot.com/2016/01/ polskie-szkoy-internetowe-ale-nie-w.html [dostęp: 26.06.2017].

Portal Edukacyjny Uniwersytetu Mikołaja Kopernika, http://portal.umk.pl/ [dostęp: 26.06.2017].

Portal historyczny polishhistory.pl, http://www.polishhistory.pl/index.php?i$\mathrm{d}=$ 97[data dostępu: 22.03.2017].

Sękowska, Elżbieta. Język emigracji polskiej w świecie: Bilans i perspektywy badawcze. Kraków: Wydawnictwo UJ, 2010. 